\title{
Community of Monogenea in populations of Cichla monoculus from two tributaries of the Amazon River in the Northern Brazil
}

\author{
M. S. B. OLIVEIRA ${ }^{1 *}$, E. APARECIDO ADRIANO2 M. TAVARES-DIAS $^{3}$, L. LIMA CORRÊA ${ }^{1,4}$
}

\begin{abstract}
1Postgraduate Program in Amazonian Continental Aquatic Resources (PPG-RACAM). Universidade Federal do Oeste do Pará UFOPA, Av. Mendonça Furtado, № 2946, Fátima, CEP 68040-470, Santarém, Pará, Brazil. Instituto de Ciências e Tecnologia das Águas - ICTA, Santarém, Pará, Brazil, "E-mail: marcosidney2012@hotmail.com; '2Department of Ecology and Evolutionary Biology, Universidade Federal de São Paulo (UNIFESP), Rua Professor Artur Riedel, 275, Jardim Eldorado, CEP 09972-270, Diadema, São Paulo, Brazil, E-mail: edapadriano@gmail.com; ${ }^{3}$ Embrapa Amapá, Rodovia Juscelino Kubitschek, Km 5, nº 2600, Universidade, CEP 68903-419, Macapá, Amapá, Brazil, E-mail: marcos.tavares@embrapa.br, ${ }^{4}$ Universidade Federal do Oeste do Pará - UFOPA, Av. Mendonça Furtado, nº 2946, Fátima, CEP 68040-470, Santarém, Pará, Brasil. Instituto de Ciências e Tecnologia das Águas - ICTA, Santarém, Pará, Brazil, E-mail: lincorre@gmail.com
\end{abstract}

\section{Article info}

Received May 4, 2018

Accepted November 9, 2018

\begin{abstract}
Summary
This study compared the monogeneans community in C. monoculus from the Tapajós River (state of Pará) and Jari River (state of Amapá), northern Brazil. A total of 2188 monogeneans belonging to eight taxa were collected from the gills of fish: Gussevia arilla, Gussevia longihaptor, Gussevia tucunarense, Gussevia undulata, Sciadicleithrum ergensi, Sciadicleithrum umbilicum, Sciadicleithrum uncinatum and Tucunarella cichlae. Gussevia arilla was the dominant species for C. monoculus from the Tapajós River basin, while S. umbilicum predominated among the hosts from the Jari River ba$\sin$. For the two populations of $C$. monoculus, the prevalence, mean intensity and mean abundance of monogeneans were different and the of parasites community had a high qualitative similarity $(87.5 \%)$. The monogeneans community of $C$. monoculus was characterized by high species richness, with infection values varying from low to moderate. The geographic distance and differences in environmental characteristics arising from the same did not influence the richness of species of monogeneans infesting C. monoculus in the Tapajós and Jari rivers, but appear to have been determinants in the differences observed in the structure of the monogenean communities in each region. Keywords: Ectoparasites; Jari River; Monogenean; Peacock bass; Tapajós River; Tucunaré
\end{abstract}

\section{Introduction}

The Tapajós River basin is formed from the confluence of the Teles Pires River and the Juruena River in the state of Mato Grosso, and flows into the middle Amazon River, in the region of Santarém, in the state of Pará (Umetsu et al., 2007). It has transparent waters and due to its distance from the sea (around $650 \mathrm{~km}$ ) suffers little influence from the tide of the Amazon River. The Jari River basin, meanwhile, is formed in the Tumucumaque Mountains National Park, on the border between Brazil and Suriname, and flows into the lower Amazon River in the south of the state of Amapá
(Amapá, 2012). Its mouth is around $270 \mathrm{~km}$ of the Atlantic Ocean, and suffers strong influence of tides of the Amazon River. For this reason, the Jari River it has white waters downstream and black waters upstream, varying the amount of organic matter in suspension (Abreu \& Cunha, 2015).

The genus Cichla Block \& Schneider, 1801 (Cichlidae) comprise 15 fish species that are popularly known as peacock bass. They are endemic to the Amazon River system and, due to the excellence of their meat are important in extractive fishery and fish farming (Batista \& Petrere Júnior, 2003; Kullander \& Ferreira, 2006; Santos et al., 2012). Cichla monoculus is widely distributed in the

\footnotetext{
* - corresponding author
} 
Amazon region and can be found from Peru to French Guiana (Kullander \& Ferreira, 2006). Due to the importance in the sport fishing, some species of Cichla have been introduced in other Brazilian river basins (Agostinho \& Júlio Júnior, 1999; Chellappa et al., 2003; Gomiero \& Braga, 2004).

Studies on parasites of wild fish populations, in addition to increasing knowledge of diversity, can generate information about the parasite-host-environment relationship (Oliveira et al., 2016; Oliveira \& Tavares-Dias, 2016). In addition, some studies have tried to elucidate the main factors that influence the parasite composition of host population (Poulin, 1995; Poulin et al., 1999; Marcogliese et al., 2006; Braicovich \& Timi, 2008; Francová \& Ondračková, 2011; Santana-Pineros, et al., 2012; Lagrue \& Poulin, 2015; Marcogliese, et al., 2016). Monogenea Van Beneden, 1858, which belongs to the Platyhelminthes Gegenbaur, 1859 phylum, is the most diverse group of parasites, with around 835 species described parasitizing fish from South America (Luque et al., 2017). While these are mainly ectoparasites of fish, and are usually found on gills, body surface and nasal cavities, but some species are endoparasites inhabiting the intestine, stomach and urinary bladder of hosts (Bilong-Bilong, et al., 1996; Guidelli et al., 2003a; Boeger \& Viana, 2006). They exhibit high host specificity in comparison with

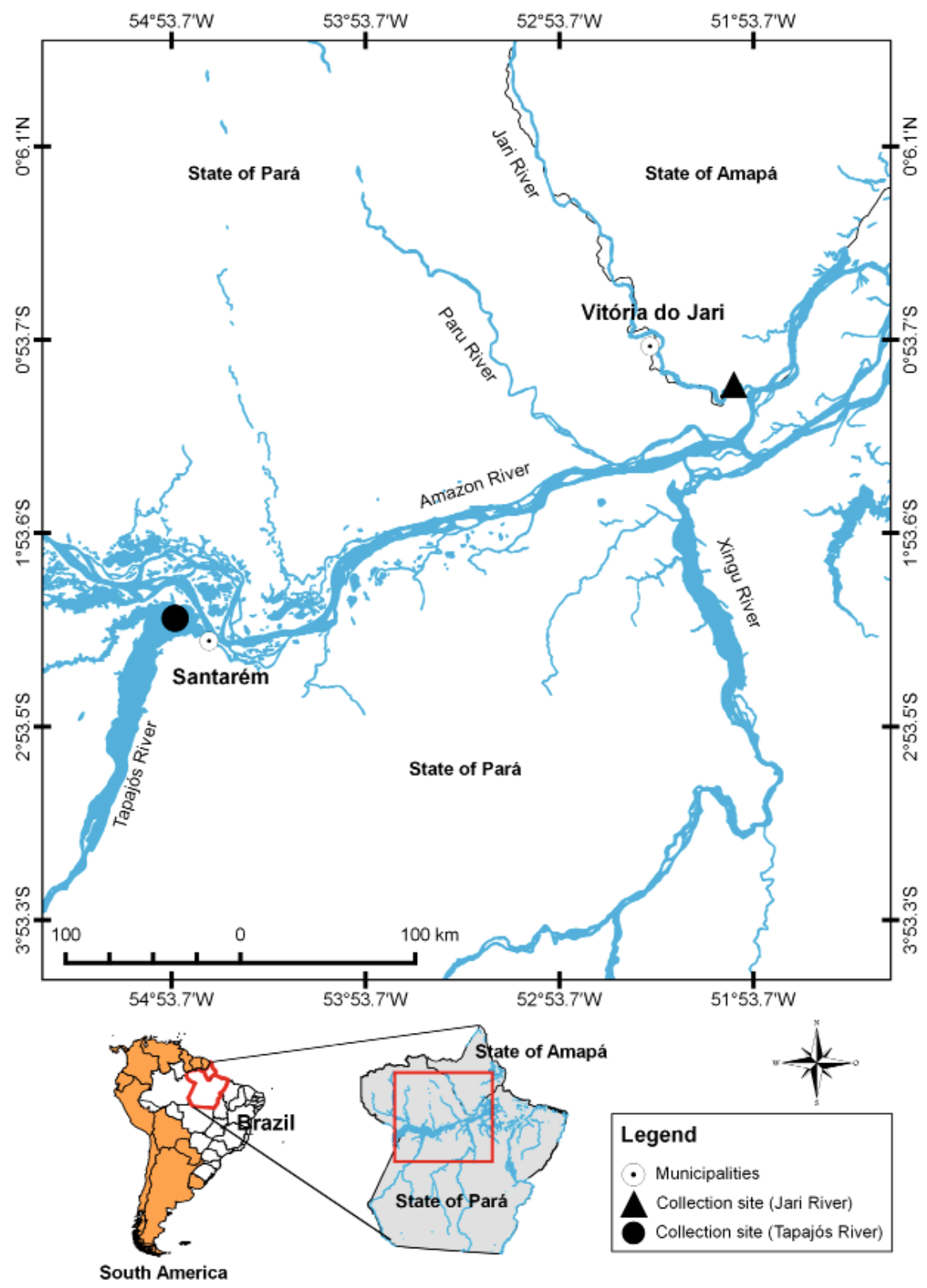

Fig. 1. Sampling sites of Cichla monoculus in the tributaries from the Amazon River, in eastern Amazon, Northern Brazil. 
other helminths taxa (Boeger \& Viana, 2006; Braga et al., 2014). In Brazil, most of the monogenean species described from freshwater fish belong to the Dactylogyridae and Gyrodactylidae families, with the dominance of dactylogyrids (Cohen et al., 2013; Luque et al., 2017). Among fish from the Cichlidae family, infestations were recorded mainly by dactylogyrids species (Cohen et al., 2013; Ferreira-Sobrinho \& Tavares-Dias, 2016). For the Cichla genus, eight species of monogeneans are known (Cohen et al., 2013), but only Gussevia Iongihaptor, Tucunarella cichlae (Mendoza-Franco, et al., 2010) and Gussevia undulata (Mendoza-Franco et al., 2010) have been recorded parasitizing C. monoculus, and such studies has been restricted to the Peruvian Amazon. Thus, this study compared the community of monogeneans in gills of $C$. monoculus from the Tapajós and the Jari rivers, both tributaries of the Amazon River system in the northern Brazil.

\section{Materials and Methods}

\section{Fish collection}

The specimens of C. monoculus were captured in March 2015 in the Jari River, near the community of Jarilândia, in the municipal of Vitória do Jari, in the state of Amapá (1 ${ }^{\circ} 7^{\prime} 39.48$ "S - 51 $\left.{ }^{\circ} 59^{\prime} 43.94^{\prime \prime} \mathrm{W}\right)$ and in the Tapajós River, near the community of Jari do Socorro, in the municipal of Santarém, in the state of Pará, Brazil $\left(2^{\circ} 20^{\prime} 2.58^{\prime \prime}\right.$ S 5452'34.08" W) (Fig. 1).

These two locations are approximately $320 \mathrm{~km}$ apart in a straight line. Gillnets measuring $30 \mathrm{~m}$ in length and $2.5 \mathrm{~m}$ in height, and with a mesh size of 30,35 and $40 \mathrm{~mm}$ between knots were used to capture the fish, along with artificial bait. The fish were identified in accordance with Kullander \& Ferreira (2006). Voucher specimens were deposited at the Platyhelminthes of the Zoology Museum (ZUEC) from the Universidade Estadual de Campinas (Campinas Federal University - Brazil), under accession number 94 - 99, 101, 104 - 109, 111 - 113, 115, 121 - 135.

\section{Collection, fixation and identification of parasites}

Following collection, the fish were euthanized by spinal cord transection. Their standard length and weight $(\mathrm{g})$ were then measured, and they were necropsied for the removal of the gills, which were transferred to flasks containing heated water $\left(60-70^{\circ} \mathrm{C}\right)$ and shaken vigorously for detachment of the parasites (Kritsky \& Stockwell, 2005). The collected monogenea were fixed in formalin $5 \%$ for $24 \mathrm{~h}$ and preserved in alcohol $70 \%$. The methodology used to quantify the parasites was that recommended by Eiras et al. (2006), and identification was in accordance with Kritsky et al. (1986), Kritsky et al. (1989) and Mendoza-Franco et al. (2010).

\section{Data analysis procedures}

The prevalence, mean intensity, mean abundancy (Bush et al., 1997) and frequency of dominance, i.e. percentage of infracommunities in which a given species of parasite is numerically dominant were determined (Rohde et al., 1995). The differences in prevalence for each species of monogenean from the host populations were evaluated using the Williams' G-test with Yates's correction; and the differences in abundance and intensity were compared using the Mann-Whitney test (U) (Zar, 2010).

To test the differences between the monogenean communities of C. monoculus, Tapajós River and Jari River, the (ANOSIM) test was used with 999 permutations using the similarity index Jaccard (J) (qualitative), and dissimilarity index of Bray-Curtis (B) (quantitative). Principal Component Analysis (PCA) was carried out to compare the monogenean communities in the gills of fish from both hydrographic basins. These analyzes were carried out using the Past-Paleontological Statistics software package (Hammer et al., 2001).

\section{Ethical Approval and/or Informed Consent}

The fish capture was authorized by the Ministry of the Environment (SISBIO $n^{\circ} 44268-4$ ) and the methodology of the present study was approved by the Ethics Research Committee of the Universidade Federal de São Paulo (São Paulo Federal University) (CEUA No 92090802140) in accordance with Brazilian legislation (Federal Law 11794, dated October 8, 2008).

\section{Results}

The 19 specimens of $C$. monoculus from the Tapajós River measured $37.4 \pm 2.6 \mathrm{~cm}$ and weighed $657.5 \pm 142.5 \mathrm{~g}$, and the 20 specimens from the Jari River measured $29.9 \pm 3.7 \mathrm{~cm}$ and weighed $737.0 \pm 240.1 \mathrm{~g}$. All the fish examined were parasitized by species of monogeneans one or more species. A total of 561 monogeneans were collected from $C$. monoculus from the Tapajós River and 1627 from the Jari River, totaling 2188 parasites. These parasites were distributed into the following taxa: Gussevia arilla Kritsky, Thatcher \& Boeger, 1986; Gussevia longihaptor Kritsky, Thatcher \& Boeger, 1986; Gussevia tucunarense Kritsky, Thatcher \& Boeger, 1986; Gussevia undulata Kritsky, Thatcher \& Boeger, 1986; Sciadicleithrum ergensi Kritsky, Thatcher \& Boeger, 1989; Sciadicleithrum umbilicum Kritsky, Thatcher \& Boeger, 1989; Sciadicleithrum uncinatum Kritsky, Thatcher \& Boeger, 1989 and Tucunarella cichlae Mendoza-Franco, Scholz \& Rozkošná, 2010. Gussevia arilla was the dominant species in the C. monoculus population from the Tapajós River, and S. umbilicum was the dominant species in hosts from the Jari River. Of these eight species of monogeneans found, seven species were commons for hosts of both basins, but $T$. cichlae occurred only in hosts from the Tapajós River. The infestation levels of monogenean species varied among themselves and between the regions studied. In hosts from the Tapajós River, the highest values of infestation were caused by G. arilla and S. umbilicum, and in the Jari River by S. umbilicum and $S$. ergensi. The lowest values of infestation in fish from the Tapajós River were caused by G. undulata and in the Jari River by T. cichlae of (Table 1). 


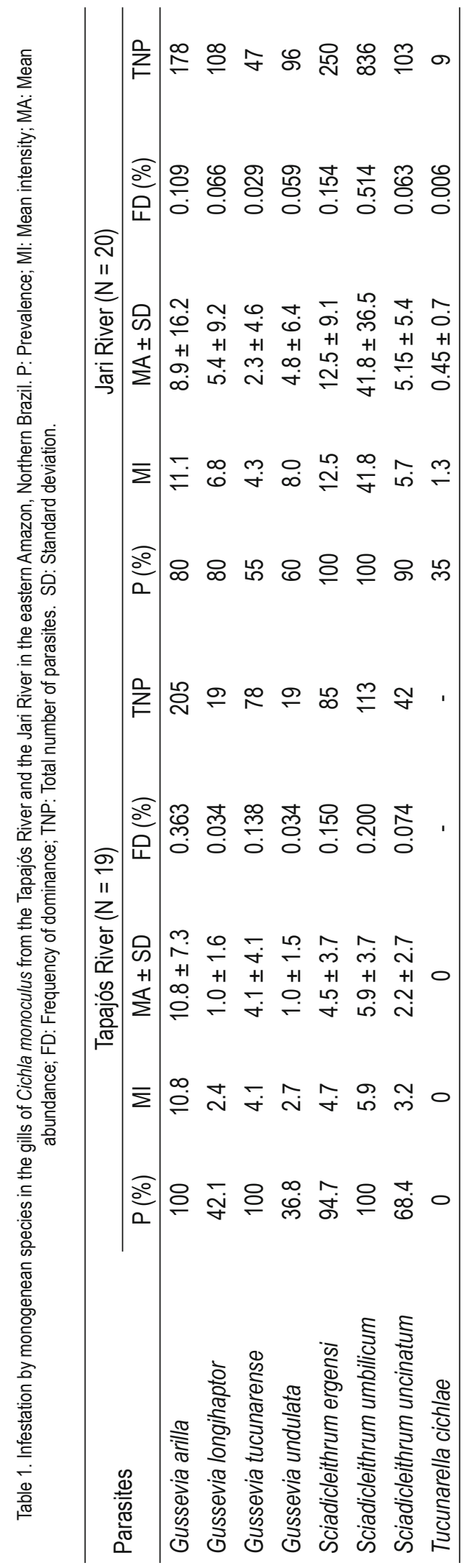


Table 2. Williams' G-test $(G)$, and Mann-Whitney $(U)$ test, considering $(p \leq 0.05)$, for levels of monogenean infestation in the gills of Cichla monoculus from the Tapajós River and the Jari River in the eastern Amazon region, Northern Brazil. P: prevalence; MI: Mean intensity; MA: mean abundance.

\begin{tabular}{lcccccc}
\hline \multirow{2}{*}{ Parasites } & \multicolumn{2}{c}{$\mathrm{P}(\%)$} & \multicolumn{3}{c}{$\mathrm{Ml}$} & \multicolumn{2}{c}{$\mathrm{MA}$} \\
\cline { 2 - 7 } & $\mathrm{G}$ & $\mathrm{p}$ & $U$ & $\mathrm{p}$ & $U$ & $\mathrm{P}$ \\
\hline Gussevia arilla & 5.17 & 0.10 & 93.50 & 0.03 & 93.50 & 0.003 \\
Gussevia longihaptor & 6.09 & 0.01 & 46.50 & 0.14 & 100.50 & 0.006 \\
Gussevia tucunarense & 14.61 & 0.0001 & 92.50 & 0.30 & 92.50 & 0.003 \\
Gussevia undulata & 2.11 & 0.15 & 21.00 & 0.03 & 125.00 & 0.03 \\
Sciadicleithrum ergensi & 1.47 & 0.23 & 78.50 & 0.001 & 78.50 & 0.0009 \\
Sciadicleithrum umbilicum & - & - & 24.00 & 0.0001 & 24.00 & 0.0001 \\
Sciadicleithrum uncinatum & 2.87 & 0.10 & 79.50 & 0.07 & 111.50 & 0.01 \\
\hline
\end{tabular}

There were significant differences in the prevalence, mean intensity and mean abundance of monogeneans for both host populations (Table 2). The monogeneans community of $C$. monoculus of the Tapajós River and Jari River presented homogeneity according to the qualitative index Jaccard $(\mathrm{J}=0.875)(R=0.370, \mathrm{p}=$ $0.001)$ and quantitative index Bray-Curtis $(B=0.459)(R=0.643$, $p=0.001$ ).

A positive correlation was observed between the abundance of monogeneans in C. monoculus (Table 3). In fish from the Tapajós River, were predominant hosts with $5-6$ species of parasites, while in fish from the Jari River there was a predominance of hosts with $4-8$ species of monogeneans (Fig. 2). Multivariate analysis of the monogenean communities of $C$. monoculus from the Tapajós and Jari rivers revealed small differences between the host populations, caused by G. arilla and S. umbilicum (Fig. 3).

\section{Discussion}

Fish have an important role in the life cycle of various species of monoxenic parasites (Hoffman, 1999; Thatcher, 2006; Oliveira et al., 2016), including monogenean species. These associations are highly complex and dynamic, resulting from the interaction of evolutionary systems and ecological processes acting simultaneously (Alarcos \& Timi, 2012). Therefore, phylogenetically proximal fish populations, living in the same environment, can exhibit major similarity in the community and richness of parasite species (Alarcos \& Timi, 2012; Hoshino \& Tavares-Dias, 2016; Oliveira et al., 2016). In contrast, when great distances separate such host populations, these similarities tend to diminish (Poulin et al., 1995; Poulin \& Morand, 1999; Lagoue \& Poulin, 2015). The community of monogeneans of $C$. monoculus from the Tapajós River and Jari

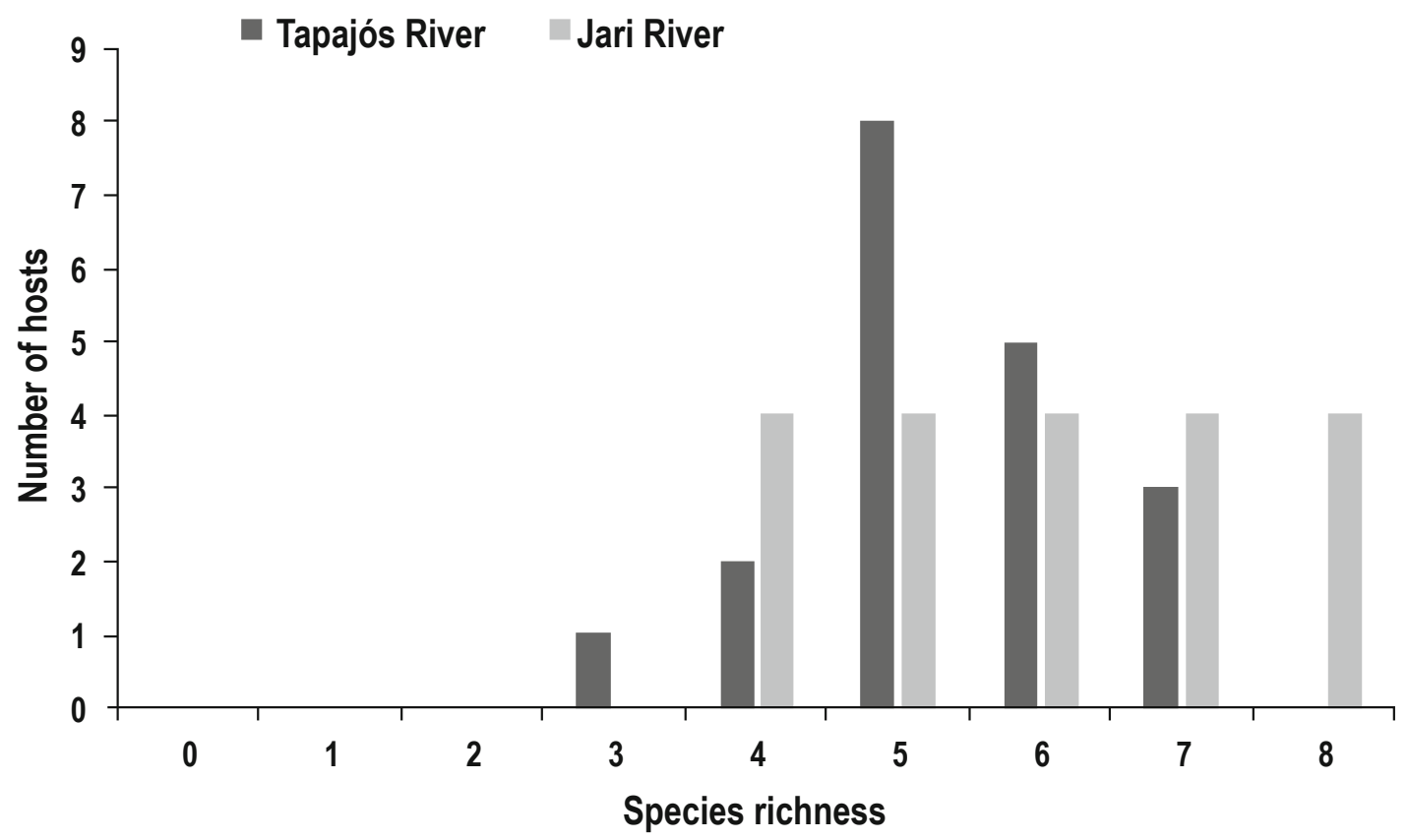

Fig. 2. Species richness of monogeneans in the gills of Cichla monoculus from the Tapajós River and the Jari River in the eastern Amazon, Northern Brazil. 


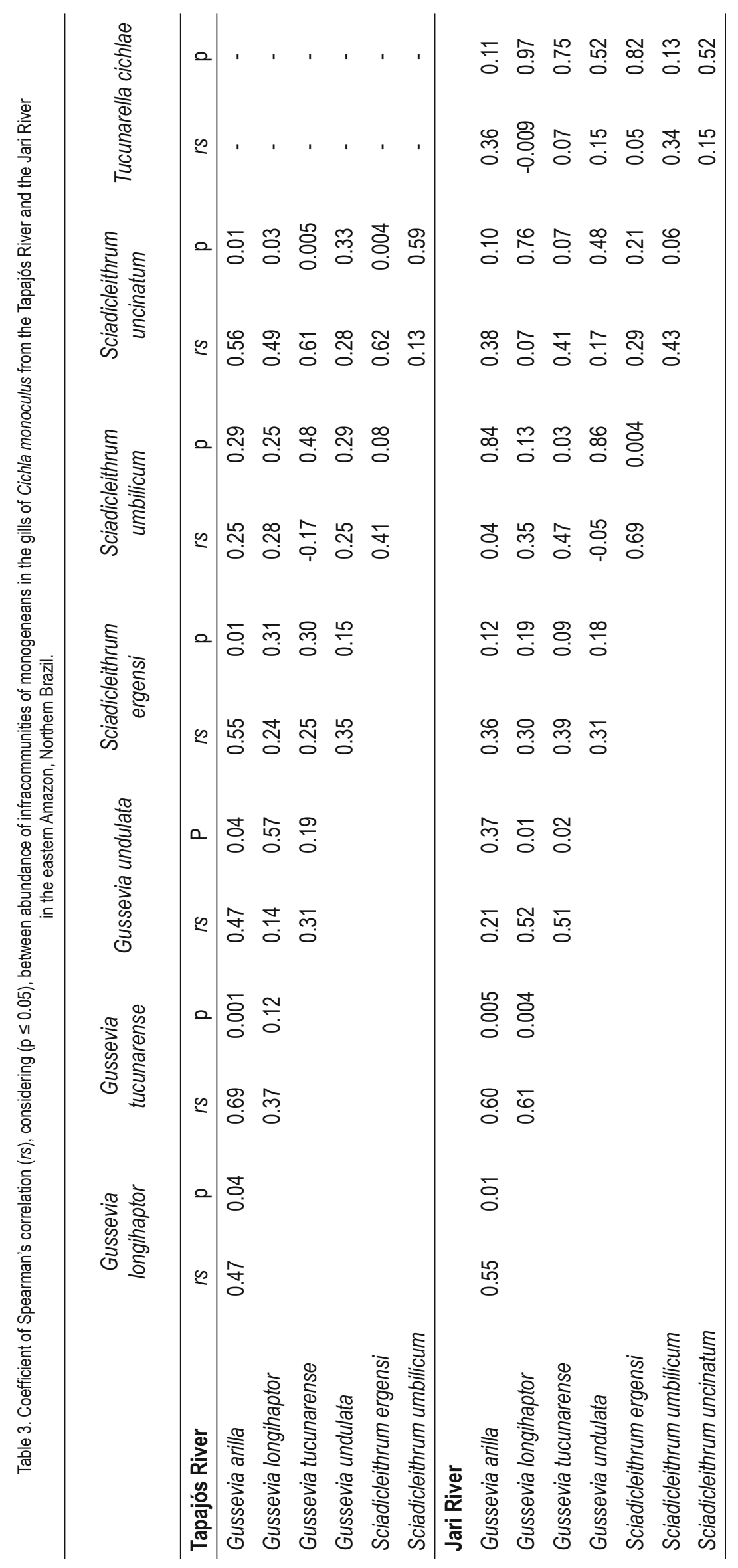




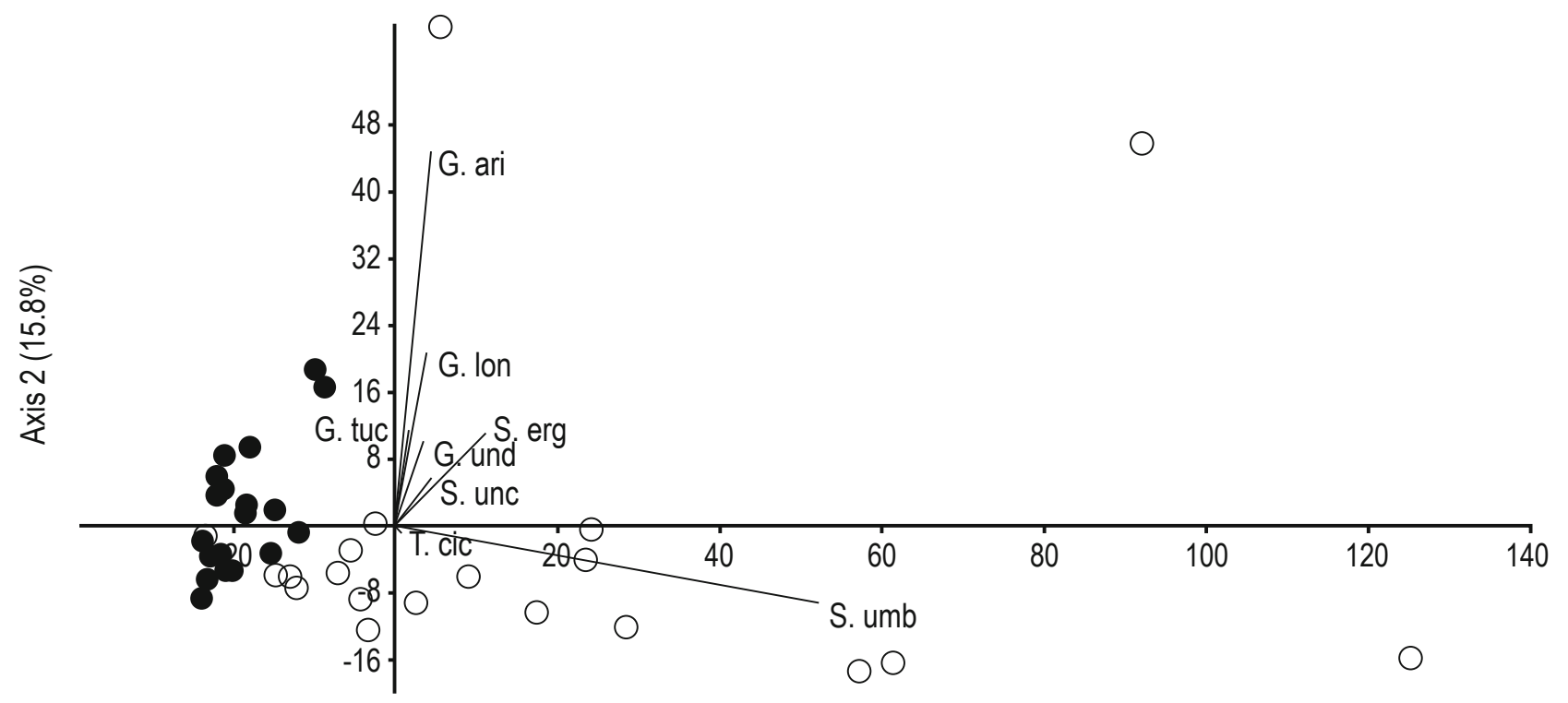

Axis 1 (79.6\%)

Fig. 3. Scatter plot of principal component analysis (PCA) of infracommunities of monogenea from the gills of Cichla monoculus from the Tapajós River (O) and the Jari River $(\mathbf{O})$ in the eastern Amazon, Northern Brazil. G. ari: Gussevia arilla; G. Ion: Gussevia longihaptor; G. tuc: Gussevia tucunarense; G. und: Gussevia undulata; S. erg: Sciadicleithrum ergensi; S. umb: Sciadicleithrum umbilicum; S. unc: Sciadicleithrum uncinatum; T. cic: Tucunarella cichlae.

River had a similarity of $87.5 \%$, and this similar composition can be expected for a same species of similar environment (Oliveira et al., 2017).

The Cichla species includes typically sedentary fish species, whose movements are restricted to a few kilometers (Hoeinghaus et al., 2003). The composition and structure of the monogenean communities of $C$. monoculus, a widely-distributed fish in the Amazon region (Kullander \& Ferreira, 2006; Willis et al., 2007), from two rivers $320 \mathrm{~km}$ apart, was compared. Cohen et al. (2013) listed eight species of monogeneans described for Cichla species, and we found these same species in C. monoculus from the Jari River, and only seven in hosts from the Tapajós River, which not had $T$. cichlae. These absence of $T$. cichlae of $C$. monoculus from the Tapajós River may be due to the low sampling of fish. In comparison with other studies, the species richness of monogeneans found here was greater than that registered for Cichla kelberi Kullander \& Ferreira, 2006 from the Paraná River basin (Takemoto et al., 2009), Rosana Reservoir (Yamada \& Takemoto, 2013) and Laje Reservoir (Yamada \& Takemoto, 2011), as well as for Cichla piquiti Kullander \& Ferreira, 2006 from the Itaipu Reservoir (Yamada \& Takemoto, 2011). However, all these studies were carried out with species of Cichla introduced into such watersheds, a condition that certainly influenced the diversity of the monogeneans of these hosts, because the parasites loss can occur after introduction into a new environment (Lacerda et al., 2013).

The present study, besides extending the knowledge of the geographic distribution of monogeneans for species of Cichla, also provides comparative data on species richness, prevalence, mean intensity and mean abundance, which are of great importance in the understanding in parasite-host-environment interaction. The Tapajós and Jari rivers are large tributaries of the Amazon River system and have their own environmental characteristics, due to the location of their mouths, and thus suffer differing influences from the waters of the Amazon River, due to the occurrence of daily tides in the Jari River (Abreu \& Cunha, 2015). Daily tides of Amazon River can directly affect the local biota of its tributaries (Junk, 2013). The similar species richness and structure of the monogenean communities from the two populations of $C$. monoculus suggest the wide distribution of parasites of this host throughout its area of occurrence in the Amazonian biome. However, the community structure of these parasites revealed different levels of prevalence and abundance, as well as the dominance of $G$. arilla in $C$. monoculus from the Tapajós River and dominance of $S$. umbilicum in hosts from the Jari River. Similarly, differences in the structure of the parasite communities related to the characteristics of each environment have been reported for different host species (Paulin \& Morand, 1999; Francová \& Ondračková, 2011; Santana-Pineros et al., 2012; Marcogliese et al., 2016).

Levels of parasitism for the same host can vary spatially, with higher values at sites where hosts are more abundant and environmental conditions are more suitable for development, transmission and survival during the free-living and infectious stages of the parasites (Lagrue \& Poulin, 2015). Possibly, differences in environmental characteristics influenced the levels of parasitism in C. monoculus, because the prevalence of G. arilla and G. tucunarense was greater in hosts from the Tapajós River, while the 
prevalence of $G$. longihaptor was greater in hosts from the Jari River. The mean intensity of G. arilla, G. tucunarense, $G$. undulata, $S$. ergensi and $S$. umbilicum was greater in fish from the Jari River, as was the abundance of $G$. longihaptor, $G$. undulata, S. ergensi, S. umbilicum and $S$. uncinatum.

In C. monoculus from the Tapajós River there was a predominance of hosts infested by five to six species of monogeneans, while in fish from the Jari River there was a predominance of hosts with four to eight species. Such differences can be related to the low abundance and mean intensity of some species of monogeneans in the gills of hosts from the Tapajós River, resulting in greater micro-habitat availability for the establishment of different monogenean infracommunities. Competition among species of parasites can be verified by the negative correlation between the abundance of the same (Šimková et al., 2000). However, only significant positive correlations were found between the abundance of the monogenean species from the Tapajós and Jari rivers, suggesting that there no competition among species, which can facilitate the coexistence of these parasites in the gills (Desdevises et al., 2000). Oliveira \& Tavares-Dias (2016) also reported similar results for Piaractus brachypomus parasitized by Anacanthorus spathulatus, Mymarothecium viatorum and Notozothecium janauachensis. In summary, this study increased the knowledge on the diversity of monogeneans in $\mathrm{C}$. monoculus from the Amazon basin, and showed a moderate parasitism in the host population, which had an aggregate dispersion of parasites. The $C$. monoculus population of both localities shared the mostly of the species of monogeneans, as expected. However, were found differences in the levels of infection by monogeneas in both host populations, influenced by geographic distance and the differences in the environmental characteristics, which is peculiar to each basin investigated. Further studies should focus on the environmental characteristics and seasonality of monogeneans in C. monoculus from these two Amazonian basins.

\section{Conflict of Interest}

Authors state no conflict of interest.

\section{Acknowledgements}

The authors would like to thank the Coordination for the Improvement of Higher Level Personnel (CAPES, Brazil) for the master's grant awarded to M.S.B. Oliveira. This study was supported by the São Paulo State Research Foundation (FAPESP, Brazil, Proc. 2013/21374-6 for E.A. Adriano). M. Tavares-Dias (Proc: 303013/2015-0) and E. A. Adriano received productivity scholarships from CNPq, Brazil. The authors would like to thank the fishermen of the communities of Jari do Socorro, in the municipal region of Santarém (state of Pará) and Jarilândia, in the municipal region of Vitória do Jari (state of Amapá), for the welcome provided and their help with fish capturing.

\section{References}

Abreu, C.H.M., Cunha, A.C. (2015): Qualidade da água em ecossistemas aquáticos tropicais sob impactos ambientais no baixo Rio Jari-AP: Revisão descritiva [Water quality in tropical aquatic ecosystems under environmental impacts on the lower Jari-AP River: Descriptive review]. BiotaAmazon., 5: 119-131. DOI: 10.18561/21795746/biotaamazonia.v5n2p119-131 (In Portuguese)

Agostinho, A.A., Júlıo, JR H.F. (1999): Peixes da bacia do alto rio Paraná [Fish from the upper Paraná River basin]. In: LowE-McConNELL, R.H. (Ed). Estudos ecológicos de comunidades de peixes tropicais. [Ecological studies of tropical fish communities]. São Paulo, SP, Edusp, pp. 374 - 400 (In Portuguese)

Alarcos, A.J., TimI, J.T. (2012): Parasite communities in three sympatric flounder species (Pleuronectiformes: Paralichthyidae): similar ecological filters driving toward repeatable assemblages. Parasitol. Res., 110(6): 2155 - 2166. DOI: 10.1007/s00436-011-2741-5 AmapÁ. (2012): Áreas protegidas do Estado do Amapá [Protected areas of the State of Amapá]. Coordenação geoprocessamento e tecnologia da informação ambiental (CGTIA). Macapá, 113 p. (In Portuguese)

Batista, V.D.S., Petrere Júnior, M. (2003): Characterization of the commercial fish production landed at Manaus, Amazonas State, Brazil. Acta Amazon., 33(1): 53 - 66. DOI: 10.1590/18094392200331066

BILONG-BILONG, C.F., Euzet, L., BIRGI, E. (1996): Monogenean stomach parasites of cichlid fishes from Cameroon: Tow new species of the genus Esterogyrus Paperna, 1963 (Ancyrocepalidae). Syst. Parasitol., 34(1): $37-42$

Boeger, W.A., Viana, R.T. (2006): Monogenoidea. In: Thatcher, V.E (Ed). Amazon fish parasites. $2^{\text {nd }}$ Edition, Moscow, Pensoft Publishers Sofia, pp. $42-116$

Braga, M.P., Araújo, S.B., Boeger, W.A. (2014): Patterns of interaction between Neotropical freshwater fishes and their gill Monogenoidea (Platyhelminthes). Parasitol. Res., 113(2): 481 - 490. DOI: 10.1007/s00436-013-3677-8

BRAICOVICH, P.E., TIMI, J.T. (2008): Parasites as biological tags for stock discrimination of the Brazilian flathead Percophis brasiliensis in the south-west Atlantic. J. Fish. Biol., 73(3): 557 - 571. DOI: 10.1111/j.1095-8649.2008.01948.x

Bush, A.O., LAFFerTy, K.D., LOTZ, J.M., Shostak, W. (1997): Parasitology meets ecology on its own terms: Margolis et al. Revisited. J. Parasitol., 83(4): 575 - 583. DOI: 10.2307/3284227

Chellappa, S., CÂmara, M.R., Chellappa, N.T., Beveridge, M.C.M., HuntingFORd FA. (2003): Reproductive ecology of a neotropical Cichlid fish, Cichla monoculus (Osteichthyes: Cichlidae). Braz. J. Biol., 63(1): 17 - 26. DOI: 10.1590/S1519-69842003000100004 Cohen, S.C., Justo, M.C.N., Kohn, A. (2013): South American monogenoidea parasites of fishes, amphibians and reptiles. Rio de Janeiro, RJ, Oficina de Livros, 662 pp.

Delgado, P.M., Delgado, J.P.M., Orbe, R.I. (2012): Massive infestation by Gussevia undulata (Platyhelminthes: Monogenea: 
Dactylogyridae) in fingerlings of Cichla monoculus cultured in the Peruvian Amazon. Neotrop. Helminthol., 6(2): 231 - 237

Desdevises, Y., Gelnar, M., Morand, S. (2000): Co-existence of nine gill ectoparasites (Dactylogyrus: Monogenea) parasitising the roach (Rutilus rutilus L.): history and present ecology. Int. J. Parasitol., 30(10): 1077 - 1088. DOI: 10.1016/S0020-7519(00)00098-9 EiRas, J.C., Takemoto, R.M., Pavanelli, G.C. (2006): Métodos de estudo e técnicas laboratoriais em parasitologia de peixes [Methods of study and laboratory techniques in fish parasitology]. Maringá, PR, Eduem, 199 pp. (In Portuguese)

Ferreira-Sobrinho, A., Tavares-Dias, M. (2016): A study on monogenean parasites from the gills of some cichlids (Pisces: Cichlidae) from the Brazilian Amazon. Rev. Mex. Biodivers., 87(3): 1002 - 1009. DOI: 10.1016/j.rmb.2016.06.010

FrancovÁ, K., OndRaČKovÁ, M. (2011): Host-parasite interactions in sympatric and allopatric populations of European bitterling. Parasitol. Res., 109(3): 801 - 808. DOI: 10.1007/s00436-011-2326-3 Gomero, L.M., Braga, F.M.D.S. (2004): Feeding of introduced species of Cichla (Perciformes, Cichlidae) in Volta Grande reservoir, River Grande (MG/SP). Braz. J. Biol., 64(4): 787 - 795. DOI: 10.1590/S1519-69842004000500008

Guidelli, G.M., Takemoto, R.M., Pavanelli, G.C. (2003): A new species of Kritskyia (Dactylogyridae, Ancyrocephalinae), parasite of urinary bladder and ureters of Leporinus lacustris (Characiformes, Anostomidae) from Brazil. Acta Sci. Biol. Sci., 25(2): 279 - 282

Hammer, O., Harper, D.A.T., RyAn, P.D. (2001): PAST: paleontological statistics software package for education and data analysis.

Palaeont. Electron., 4: 1 - 9

Hoeinghaus, D.J., Layman, C.A., Arrington, D.A., Winemiller, K.O. (2003): Movement of Cichla species (Cichlidae) in a Venezuelan floodplain river. Neotrop. Ichthyol., 1(2): 121 - 126. DOI: 10.1590/ S1679-62252003000200006

HoffmAn, G.L. (1999): Parasites of North American freshwater fishes, $2^{\text {nd }}$ Edition, Cornell University Press, $539 \mathrm{p}$.

Hoshino, M.D.F.G., Neves, L.R., TaVARES-Dias, M. (2016): Parasite communities of the predatory fish, Acestrorhynchus falcatus and Acestrorhynchus falcirostris, living in sympatry in Brazilian Amazon. Braz. J. Vet. Parasitol., 25(2): 207 - 216. DOI: 10.1590/ S1984-29612016038

Junk, W.J. (2013): Current state of knowledge regarding South America wetlands and their future under global climate change. Aquat. Sci., 75(1): 113 - 131. DOI: 10.1007/s00027-012-0253-8 KRITSKY, D.C., StOCKWELL, C.A. (2005): New species of Gyrodactylus (Monogenoidea, Gyrodactylidae) from the white sands pupfish, Cyprinodon tularosa, in New Mexico. Southwest. Nat., 50(3): 312 - 317. DOI: 10.1894/0038-4909(2005)050[0312:NSOGMG]2.0. $\mathrm{CO} ; 2$

Kritsky, D.C., Thatcher, V.E., Boeger, W.A. (1986): Neotropical Monogenea. 8. Revision of Urocleidoides (Dactylogyridae, Ancyrocephalinae). Proc. Helminthol. Soc. Wash., 53(1): $1-37$

KRITSKY, D.C., Thatcher, V.E., Boeger, W.A. (1989): Neotropical Monogenea. 15. Dactylogyrids from the gills of Brazilian Cichlidae with proposal of Sciadicleithrum gen. n. (Dactylogyridae). Proc. Helminthol. Soc. Wash., 56(2): $128-140$

Kullander, S.O., FerreiRa, E.J.G. (2006): A review of the South American cichlid genus Cichla, with descriptions of nine new species (Teleostei: Cichlidae). Ichthyol. Explor. Freshw., 17(4): 289 $-398$

Lacerda, A.C., Yamada, F.H., Antonucci, A.M., Tavares-Dias, M. (2013): Peixes introduzidos e seus parasitos [Introduced fish and their parasites]. In: Pavanelli, G.C., Takemoto, R.M., Eiras, J.C. (Eds). Patologia de peixes de água doce do Brasil [Parasitology of freshwater fish of Brazin. Maringá, Eduem, pp. 59 - 80 (In Portuguese)

LAgrue, C., Poulin, R. (2015): Spatial covariation of local abundance among different parasite species: the effect of shared hosts. Parasitol. Res., 114(10): 3637 - 3643. DOI: 10.1007/s00436-0154590-0

LUdWIG, J.A., ReYNoldS, J.F. (1988): Statistical ecology: a primer on methods and computing. New York, Wiley-Interscience Pub, $337 p$.

Luque, J.L., PereiRa, F.B., Alves, P.V., Oliva, M.E., Timi, J.T. (2017): Helminth parasites of South American fishes: current status and characterization as a model for studies of biodiversity. J. Helminthol., 91 (2): 150 - 164. DOI: 10.1017/S0022149X16000717 MagurRan, A.E. (2004): Measuring biological diversity. Oxford (UK), Blackwell Science, $215 p$.

Marcogliese, D.J., Gendron, A.D., Plante, C., Fournier, M., Cyr, D. (2006): Parasites of spottail shiners (Notropis hudsonius) in the St. Lawrence River: effects of municipal effluents and habitat. Can. J. Zool., 84(10): 1461 - 1481. DOI: 10.1139/Z06-088

Marcogliese, D.J., Locke, S.A., Gelinas, M., Gendron, A.D. (2016): Variation in parasite communities in spottail shiners (Notropis hudsonius) linked with precipitation. J. Parasitol., 102(1): 27 - 36. DOI: 10.1645/12-31

Mendoza-Franco, E.F., Scholz, T., RozkošnÁ, P. (2010): Tucunarella n. gen. and other Dactylogyrids (Monogenoidea) from Cichlid Fish (Perciformes) from Peruvian Amazonia. J. Parasitol., 96(3): 491 498. DOI: $10.1645 / G E-2213.1$

Moura, M.A.M., KubitzA, F., CYrino, J.E.P. (2000): Feed training of peacock bass (Cichla sp.). Rev. Brasil. Biol., 60(4): 645 - 654 . DOI: 10.1590/S0034-71082000000400015

Oliveira, M.S.B., Gonçalves, R.A., Tavares-Dias, M. (2016): Community of parasites in Triportheus curtus and Triportheus angulatus (Characidae) from a tributary of the Amazon River system (Brazil). Stud. Neotrop. Fau. E., 51(1): 29 - 36. DOI: 10.1080/01650521.2016.1150095

Oliveira, M.S.B., Gonçalves, R.A., Ferreira, D.O., Pinheiro, D.A., Neves, L.R., Dias, M.K.R., Tavares-Dias, M. (2017): Metazoan parasite communities of wild Leporinus friderici (Characiformes: Anostomidae) from Amazon River system in Brazil. Stud. Neotrop. Fau. E., 52(2): 146 - 156. DOI: 10.1080/01650521.2017.1312776 Oliveira, M.S.B., TAVARES-Dias, M. (2016): Communities of parasite metazoans in Piaractus brachypomus (Pisces, Serrasalmidae) in 
the lower Amazon River (Brazil). Rev. Bras. Parasitol. Vet., 25(2): 151 - 157. DOI: 10.1590/S1984-29612016022

Poulin, R., Morand, S. (1999): Geographical distances and the similarity among parasite communities of conspecific host populations. Parasitology, 119(4): 369 - 374

Poulin, R. (1995): Phylogeny, ecology, and the richness of parasite communities in vertebrates. Ecol. Monogr., 65(3): 283 - 302. DOI: 10.2307/2937061

Rohde, K., Hayward, C., Heap, M. (1995): Aspects of the ecology of metazoan ectoparasites of marine fishes. Int. J. Parasitol. 25(8): 945 - 970. DOI: 10.1016/0020-7519(95)00015-T

Santana-Pineros, A.M., Pech, D., Vidal-Martinez, V.M. (2012). Spatial structure of the helminth parasite communities of the tonguefish, Symphurus plagiusa, from the Campeche coast, southern Mexico. Int. J. Parasitol., 42(10): 911 - 920. DOI: 10.1016/j.jjpara.2012.07.008

Santos, C.H.S., Sousa, C.F.S., Paula-Silva, M.N., Val, A.L., AlmelDA-VAL, V.M.F. (2012): Genetic diversity in Cichla monoculus (Spix and Agassiz, 1931) populations: implications for management and conservation. Am. J. Environ. Sci., 8(1): 35 - 41

Šimková, A., Verneau, O., Gelnar, M., Morand, S. (2006): Specificity and specialization of congeneric monogeneans parasitizing cyprinid fish. Evolution, 60(5): 1023 - 1037. DOI: 10.1554/05-521.1

Takemoto, R.M., Pavanelli, G.C., Lizama, M.A.P., Lacerda, A.C.F.,
Yamada, F.H., Moreira, L.H.A., Bellay, S. (2009): Diversity of parasites of fish from the upper Paraná River floodplain, Brazil. Braz. J. Biol., 69(2): 691 - 705. DOI: 10.1590/S1519-69842009000300023 Thatcher, V.E. (2006): Amazon Fish Parasites, $2^{\text {nd }}$ Edition, Moscow, Pensoft Publishers Sofia, $507 \mathrm{p}$.

Umetsu, C.A., Umetsu, R.K., Munhoz, K.C.A., Dalmagro, H.J., KrusCHE, A.V. (2007): Aspectos físico-químicos de dois rios da bacia do alto Tapajós - Teles Pires e Cristalino-MT, durante período de estiagem e cheia [Physicochemical aspects of two rivers of the upper Tapajós basin - Teles Pires and Cristalino-MT, during drought and flood]. Rev. Cien. Agroambient. 5(1): 59 - 70 (In Portuguese) Willis, S.C., Nunes, M.S., Montaña, C.G., Farias, I.P., Lovejoy, N.R. (2007): Systematics, biogeography, and evolution of the Neotropical peacock basses Cichla (Perciformes: Cichlidae). Mol. Phylogenet. Evol. 44(1): 291 -307. DOI: 10.1016/j.ympev.2006.12.014 Yamada, F.H., Santos, L.N., Takemoto, R.M. (2011): Gill ectoparasite assemblages of two non-native Cichla populations (Perciformes, Cichlidae) in brazilian reservoirs. J. Helminthol. 85(2): 185 - 191. DOI: 10.1017/S0022149X10000441

YAMADA, F.H., TAKEMOTO, R.M. (2013): Metazoan parasite fauna of two peacock-bass cichlid fish in Brazil. Check List, 9(6): 1371 1377. DOI: 10.15560/9.6.1371

ZAR, J.H. (2010): Biostatistical analysis. $5^{\text {nd }}$ Edition, New Jersey, Prentice Hall, $944 \mathrm{p}$. 